\title{
Issues in Corporate Social Responsibility Practices in Oil- Producing Communities in Rivers State, Nigeria: Implications for Community Education
}

\author{
UGWU Angela Nkechi $(\mathrm{PhD})$ \\ Department of Adult \& Non-Formal Education, Faculty of Education, University of Port Harcourt, Rivers State, \\ Nigeria.
}

Abstract

This study examined the issues in corporate social responsibility practices in oil-producing communities through a descriptive survey of oil-producing communities in three Local Government Areas in Rivers State. Corporate social responsibilities of companies to their host communities were identified, the extent to which communities benefitted from the social responsibility were ascertained and the issues arising in the implementation of the social responsibility examined. The findings showed that community's representatives mismanaged funds meant for community projects, the youths vandalized oil pipelines and indulged in crimes among others. Based on the findings, the author recommended community education as a viable tool to address the issues raised.

Keywords: Issues, Corporate Social Responsibility, Community Education

DOI: $10.7176 / \mathrm{JESD} / 11-4-23$

Publication date: February $29^{\text {th }} 2020$

\section{Introduction}

Oil companies and communities' relations in the Niger Delta region of Nigeria has inundated discussions in academic articles, the press and other media houses, international community, government and individuals since oil exploration in the region. The major issues have been centred on the depletion of the environment through oil exploration which has destroyed aquatic lives, threatened the livelihood system, and triggered a high unemployment rate among other issues. The oil companies, on the other hand, have explored avenues to secure a conducive and safe environment in other to achieve their main business objectives. This they have fairly achieved through their Corporate Social Responsibility (CSR) practices to their host communities.

CSR apart from being a pacifier to host communities to achieve a conducive working environment for their business operations is also a way of strengthening corporate relations and a statutory obligation or ethical standards expected from companies to their host communities. As Yusuf (2009) notes, it is a part of the company's policy which is integrated into a business model for an organization to be able to live in harmony with its operating environment. Companies or organizations invest in social, environmental and community programmes which leaves a footprint in the sands of development in the communities they work in. This is a way of the companies giving back to the society especially the immediate environment they operate and contributing to the socioeconomic development of the society.

In fulfilling this statutory obligations and in trying to quell the agitations of oil-producing communities, literature and experience in the field of community development show that oil companies like Total, Shell Petroleum Development Company (SPDC), Nigerian Agip Oil Company (NAOC) and other oil industries have provided some corporate social responsibilities in the areas of education, health, social welfare, human resources and capacity development and infrastructural development among others to their host communities (Total, 2016, Uzoagu, (2015) and Otamiri, (2015).

Corporate Social Responsibility attracted more attention in the Niger Delta when militant groups sprang up to protest environmental hazards from oil exploration and rising unemployment among the youths in the area. The protests snowballed into blowing of oil pipelines and kidnapping of oil workers for ransom and other restive activities. It is believed that CSR, would bring down the tension of the aggrieved youths as many. However, many communities are still embroiled in conflicts as there are emerging issues between communities and some oil companies and among community members. Some of these issues have to do with the CSR practices or implementation strategies of oil companies, employability of some of the community members and lack of skills and capacity to do certain work which have hampered community development activities. In this vent, the researcher proposes community education as a veritable instrument that can address the issues. Community 
education aims at providing the educational needs of all members of the community to be able to take care of the problems of local communities to translate opportunities into maximum development.

It is believed that through community education, community members learn to negotiate better with oil companies and community representatives which will chart way for better understanding and reduce the conflicts that have emerged through CSR practices. It is against this background that this paper examined the issues in corporate social responsibilities in oil-producing communities and how community education can address the issues to achieve sustainable community development in Rivers State.

\section{Problem of the Study}

Beyond statutory obligation, it is a moral duty for corporations or organizations to add value to the lives of the people in its operational environment. This is done in the form of provision of human resources development, socio-economic, health and infrastructural development. In the case of some oil-producing communities in Rivers State, provision of corporate social responsibilities by oil companies has brought down tension but has not provided the peaceful environment needed for community development to thrive. There have been emerging issues between oil companies and their host communities and among community members themselves. It is against this backdrop that this study examined these issues especially among community members and proposed community education as a veritable tool that can address the issues and emerging ones.

\section{Aim of the Study}

The study aims to examine issues in the corporate social responsibility practices in oil-producing communities in Rivers State and determine community education strategies that can be used to address the issues.

\section{Research Questions}

1. What are the corporate social responsibilities provided in oil-producing communities?

2. To what level has community members benefitted from the corporate social responsibilities provided for them?

3. What are the issues arising from the implementation of corporate social responsibilities?

\section{Theoretical Review}

This study is anchored on the stakeholders' theory propounded in the 80s. It is a theory introduced by Dr F. Edward Freeman and popularized in his book "Strategic Management: A Stakeholder Approach. (https:/www.smatsheet.com). Freeman's position is against Milton Friedman's 20th-century shareholder's theory which held that the only stakeholder a company should care about is its shareholders. Freeman argues in his book that managers are not just answerable to shareholders but also need to consider any group or individual who can affect or is affected by the achievement of the firm's objectives. This theory is relevant to the study because oilproducing communities are major stakeholders in the business of multinational companies especially as they (host communities) are negatively affected by oil exploration. Beyond these statutory and moral obligations of adding value to the lives of the stakeholders, the oil companies need a conducive peaceful environment to achieve their business objectives and to achieve this, their host communities need to be pacified.

\section{Conceptual Review}

For a better understanding of this work, the major concepts in the topic are reviewed below:

\section{Corporate Social Responsibility:}

There are several definitions of corporate social responsibility (CSR), however, a few of them are discussed here. It simply means the relationship of an organization or company and the environment or the society where it operates. According to Crowder and Aras (2008:10), it is the relationship between a corporation and its stakeholders. Stakeholders here include every other individual, groups and that have anything to do with the corporation. Dalthrud in Ojokheta (2018) analysed 37 definitions of corporate social responsibility and identified five key dimensions: environment, social, economic, stakeholder (those parties that have a stake in how the company operates) and voluntariness (the actions are not prescribed by law). Most definitions do not capture all the dimensions mentioned. The European Union (EU) Commission in Crowder and Aras (2018:11) defines CSR as "a concept whereby companies integrate social and environmental concerns in their business operations and their interaction with their stakeholders voluntarily". This definition did not recognize the statutory obligation of an organization especially when some of the activities of the corporations affect the environment negatively. Oppewal, Alexander and Sullivan in Kpolovie and Sado (2016:3) define CSR as a persistent commitment by a 
business organization to ethically behave to contribute maximally to the economic and environmental advancement of the quality of life of its workforce and the society particularly the host communities. The Business' Dictionary (2016a) suggests that CSR is a duty of the corporate bodies to the working environment and defines it as the obligation of an organization's management towards the welfare and interests of the society in which it operates. In the view of Moon, Corporate Social Responsibility is "the responsibility of enterprises for their impacts on society (Nabiebu, Efombruh and Udo (2019). In most definitions of CSR, it is important to note that the concept connotes a moral duty, responsibility and the voluntariness to give back to the society by impacting on the immediate environment especially where the business affects the environment negatively.

The University of Edinburgh, Career Services (2017) notes that CSR aims to ensure that companies conduct their business in a way that is ethical. This means taking account of their social, economic and environmental impact, and consideration of human rights. It further outlines the activities of CSR to include:

- Working in partnership with local communities

- $\quad$ Socially responsible investment (SRI)

- Developing relationships with employees and customers

- Environmental protection and sustainability.

From the above definitions, it is obvious that no laws expressly mandated oil companies to carry out their business operations in a specific ethical way. It is more of responsibility and moral duty to compliment government activities in promoting the socio-economic development of the society.

\section{Community Education}

Community education has been viewed in different ways by different scholars. The definitions depend on the environment and practice. In the same line of thought, Abiona, 2012 stated that in advanced countries, community education is perceived in terms of expanding existing services and resources such as those of a school available for a wider use by the local community. For instance, in England and some other countries, community education was perceived as community schooling before the 1990s (INFED, 2019). INFED further posits that in the United States of America, community education is described in relation to community Organisation. In relation to community education practice in developing countries like Nigeria, Oduaran in Ugwu and Mbalisi (2019) defines it as a problem-solving enterprise with emphasis on educational curriculum, programmes and services which aim at rejuvenating the abilities of community members for their socio-economic, cultural and political growth using all community facilities with educational purpose. FAU, 2020 viewing community education as a scenario for learning and collaboration posits that community education is an effective way of enhancing individual and community live which provides opportunities for learning and collaboration.

Though there are different perspectives in the understanding of what community education is, there seem to be consensus that community education is a life long learning process. Abiona (2012) lends support to this assertion and posits that community education is being embraced as basic education for life in the society which goes beyond education for livelihood. It is a lifelong education that can equip community members with knowledge, skills, information and attitudes that can enhance communal life using community resources.

Community education as noted by Abiona (2012), is about creating a participatory learning culture that incorporates principles and practices of respect, mutual aid, inclusiveness, lifelong learning, skill-building, selfappreciation, entrepreneurship and leadership development. These he calls the puzzle pieces that makeup community life and learning, hence its suitability for strengthening self-help groups. Literacy is another important component of community education which will facilitate and enhance other community education programmes especially lifelong learning. Abiona (2012) in support of this assertion, posits that it is easier to communicate and decide lines of action on issues involving the community if members of the community are literate.

Akande, in Ugwu (2018 p88) defines community education as the type of education needed to ensure the selfconfidence, self -respect, and personal interdependence as well as to safeguard human rights and achieve social equality. This educational approach will assist members of the community to find or generate employment, increase their incomes and improve their quality of life.

Community education is relevant in addressing the issues emanating from corporate social responsibility practices because community education is an educational practice that is locally based and non-formal. As Abiona, (2012) puts it, "community education is very relevant in the local community in that each community has different problems which can be solved by the initiatives of the community members themselves. This lends support to the 
principles of community education which emphasise the use of community resources including volunteers and education for a specific population.

Other components of community education that when effectively carried out will enhance the knowledge, skills and attitudes of community members and promote peaceful co-existence and community development are leadership development, community responsibility and inclusion, conflict management and peace building and skills acquisition.

\section{Empirical Review}

A lot of studies have been carried out in this area especially as it concerns the Niger Delta region. This is because issues arising from oil operations in the region have attracted so much attention both locally and globally. A few of them which are related to the present study are reviewed.

Musa, Yusuf, Mcardle, and Banjoko (2013) carried out a research titled "CSR in Nigeria's Oil and Gas Industries: Perspectives of the Industries. This study, though related to the present study emphasized the views of the oil companies. The findings showed that the oil industry understands the CSR as contemporary to its long-term survival in the country and that the state has not cooperated with the oil industry to give sufficient incentive and enabling environment for CSR for sustainability. The present study examined the issues in the communities from the perspectives of the community members themselves.

Igbara, Etu, Alaobari \& Naenwi (2014) assessed the CSR provided in oil-producing communities and the perceived needs of the communities. The researchers found out that what was provided and the perceived needs of the communities differ significantly. Recommendations were made on how to enhance the CRS practices that will address community needs. It relates to the present study since it identified the CSR provided to the communities, however, it did not identify the issues that hinder full benefit of the CSR in communities which the present study addressed.

Uzoagu, (2015) assessed the CSRs of SPDC and NAOC on the socio-economic development of their host communities in Rivers State. The findings of the study revealed that SPDCs CSRs were not well organized. It also noted that the responsibilities carried out were done after much conflicts, arguments, series of visits and follow-up by the communities. The study also found out that SPDC shies away from their responsibilities to the host communities. Kpolovie and Sado (2016) carried out a study on how CSR can be used for conflict resolution in the Niger Delta oil and gas industry. The study concluded that the oil industries have not done enough to achieve peaceful coexistence with their host communities. The researchers recommended that an excellent CSR through a viable strategy will end the crises between oil industries and their host communities. This study like many others emphasized the relationship between oil industries and their host communities.

As the author has noted earlier, there are uncountable studies on CSR as a veritable tool to douse the tension and myriads of associated issues triggered by environmental damage arising from oil exploration in the Niger Delta region. Most other studies have equally addressed the issues of the relevance of the CSR practices in addressing the felt needs of the communities. However, to the best of the researcher's knowledge, much has not been done on the host communities' activities that compromise the CSRs' practices of oil companies which are the major issue addressed in this study.

\section{Methodology}

The study adopted a qualitative research through Focus Group Discussion (FGD) and Semi-Structured Interview schedule in oil-producing communities in three Local Government Areas (LGAs) in Rivers State: Ahoada-West LGA (communities studied include Edagbari and Better land which comprises seven villages: Okpu-Ogubo, Okpufy, Okpu Adide, Okpu-Sheshakie, Okpu-Ebususu and Better land). Ikwerre LGA (Aluu and Igwuruta communities were studied) and Ogba/Egbema/Ndoni LGA (Obie, Oborikom, Omoku, Egbegoro and Okpsi were studied).

The choice of these Local Government Areas was informed by the previous experience of community conflicts and most of them are major oil-producing communities. A total number of 25 community members including men, women and youths were used for the study. Nine (9) were drawn from Ahoada-West, Seven (7) from Ikwerre and Nine (9) from Ogba/Egbema/Ndoni. The venue of the discussion was centralized in each LGA for easy access by the respondents. For Ikwerre, the discussions were held differently for the two communities owing to the distance between them. The questions asked addressed all the issues in the research questions.

The discussions were based on the CSRs provided for community members, the level of benefits by the communities and the issues arising from the implementation of CSRs. The researcher was assisted by three undergraduate students of Adult and Non-Formal Education Department who are from the LGAs studied. They 
taped and recorded the discussion to enable the researcher who led the discussion to maintain eye contact with the discussants or respondents. They also served as interpreters for clarifications in cases where some of the respondents used vernacular. Three lecturers who are from Aluu, Omoku and Ahoada were also interviewed to corroborate the FGD.

\section{Report of the Focus Group Discussion (FGD) and Interview Schedule from the Oil Producing Communities}

Below is the result of the focus group discussion held in the three Local Government Areas in Rivers State.

\section{Ahoada-West Local Government Area}

The respondents stated that SPDC which has 48 oil wells in the communities have provided CSRs in the communities in the following areas:

- Health care facilities (building and equipping a hospital)

- $\quad$ Steady power supply

- $\quad$ Pipe borne water

- Good road network

- Education (building of primary school) and scholarships and good learning facilities

- Cassava processing factory

- $\quad$ Oil mill and Market buildings

- Townhall

On the level of benefits of CSRs' provisions, it was gathered that community members benefitted from those facilities to a large extent. Specifically, they revealed that the steady power supply has improved business and economic activities. The educational facilities also improved children enrolment in school because of the proximity of the school. The good roads have also improved agricultural productivity as they can easily transport their goods to the market and further improved the socio-economic conditions of the community.

The discussants identified corruption on the part of community leaders and pipeline vandalism by the youths as the major issues arising from the implementation of CSRs. The issue of matching ground (money community youths demand from contractors who implement projects in the communities. Sometimes, they demand so much that the contractors are not willing or unable to pay which delays projects' completion and sometimes abandoned.

\section{Ikwere Local Government Area}

The communities studied under Ikwerre Local Government Areas are Aluu and Igwuruta communities who host Shell Petroleum Development Company (SPDC). The questions were drawn from the research questions. On the CSR provided for the communities, they all agreed that SPDC has provided power supply (electricity), payment of bursary of about N150,000 (One hundred and fifty thousand naira) only to every youth in a tertiary institution and some slots of a full scholarship and employment opportunities for some youths in Aluu community.

On the level of benefits of CSR by community members, it was gathered that every male in Aluu is entitled to a monthly salary. However, only the families that own the lands where there is oil benefit directly from the CSR in Igwuruta since SPDC gives monetary compensation. The respondents noted that for other community members to benefit from scholarship or employment, they have to buy it or pass through the leaders or people that are directly connected to the owners of the land.

On the issues arising from CSR in Ikwerre, the respondents noted that in Aluu, the bursary given to students sometimes is delayed. For instance, one of the respondents who is a student noted that this year, SPDC has not paid anyone bursary which used to be paid monthly. Both communities in Ikwerre agreed that money meant for community projects are mismanaged by community leaders or those who represent the communities. They also sell employment and scholarship slots meant for the community members to those who can afford it. 


\section{Ogba/Egbema/Ndoni Local Government Area}

The discussion in this local government area was held at Omoku community. The discussants noted their communities play host to Nigerian Agip Oil Development Company (NAOC). It was gathered that Agip, as it is mostly called, has provided its host communities with the following:

- Well-equipped school buildings

- $\quad$ Constant power supply (Electricity)

- Scholarship scheme for students in tertiary institutions

- $\quad$ Road networks

- The building of town halls and market stalls

- Skills Acquisition training for unemployed youths on various skills like tailoring, soap making, business management and planning, fish farming etc.

- Job opportunities

- $\quad$ Agricultural products (improved seedlings and fertilizer)

On the level of benefit, they stated that the communities have benefited to a great extent. For instance, youths are trained on various skills and are given startup kits or equipment to start their businesses. The training given to the community members is enough to make them self- reliant and give them economic independence.

On the issues arising from the CSRs, the respondents revealed that the majority of the recipients of skills training does not make use of the training given to them. They abandon the skill and sell off the equipment given to them to start the business. According to the respondents, cultism is another major issue. Some youths who are cultists terrorize the communities and oil workers and scare away other investors.

The result of the interviews supported the findings from the focus group discussion, however, as academics, they all emphasized ignorance, lack of awareness of some issues, corruption and greed as major hindrances to achieving development in the communities through CSRs practices of oil companies.

\section{Discussion of Findings}

On the first research question which sought to identify the corporate social responsibilities provided in oilproducing communities, all the community members agreed that oil companies have provided good road networks, educational facilities like school buildings and scholarship scheme, electricity, potable water, healthcare facilities, agricultural facilities like milling machines, skills acquisition programmes and other infrastructural development. This agrees with Uzoagu (2015) and Total (2016) who revealed that SPDC, Agip Oil and Total Oil Company have provided some development facilities to their host communities as can be seen in the report made above.

On the level of benefits, it was also generally agreed in the communities in Ahoada West that to a great or high extent, the community members benefited from the CSRs provided for them. Respondents from Ahoada West specifically mentioned educational facilities and scholarship scheme which have assisted their young ones to go to school, the electricity and good road network which have increased economic activities in the communities and made the standard of living of community members better. The improved seedlings and fertilizer given by Agip in Ogba/Egbema/Ndoni improved agricultural productivity which in turn increased economic activities for an improved standard of living. These provisions relatively reduced the conflicts between community members and the oil companies. However, respondents from Ikwerre noted that they have benefitted to a low extent since all members of the community do not benefit equally. A respondent from Igwuruta, Ikwerre Local Government Area stated that there is a popular slang in their community which says that "Owners shall Reap". This means that only those from whose lands oil is drilled directly benefit from the CSRs as the oil companies mostly pay financial compensation instead of providing facilities that will benefit the whole community. In Aluu, scholarship funds are paid directly to the students. There is more individual benefits rather than community benefits.

On the issues arising from the implementation of CSR in communities which is the focus of this study, it was revealed that in all the communities their representatives who are mostly community members have not been fair to their communities as they mismanage funds meant for community projects. They specifically mentioned that these representatives who also serve as contractors in some communities, siphon funds meant for the community 
into their coffers. Respondents in Ikwerre revealed that slots for employment and scholarship are sold to people who can afford to buy them or given to the children and relatives of the leaders instead of giving them by merit or to those who are qualified or to the indigent ones. This they said has pitched the youths against the leaders and has also increased leadership tussle in such communities as everyone wants to clinch the juicy positions of being a contractor or Community Development Committee (CDC) member or Chairman.

The respondents mostly in Ahoada noted that oil pipeline vandalism and illegal refining of oil by some youths in the community is a major concern to them as a community. They stated that these activities affect the exploration of oil by the oil companies and also affect their river and soil which in turn have effects on the community members' health and their agricultural activities.

The discussion revealed that the community leaders and those who have direct contact with the oil companies divert the funds meant for community projects into their coffers. The issue of matching ground (money community youths demand from contractors who implement projects in the communities) scare contractors away from the communities. Sometimes, they demand so much that the contractors are not willing or are unable to pay. This leads to project delay or total abandonment of community projects.

The respondents noted with regrets that the majority of those who receive training in various skills especially the youths do not practice them. They sell off the equipment given to them to start their businesses and stay idle in the community thereby causing nuisance and increase the rate of crime in the communities. Cultism in $\mathrm{Ogba} /$ Egbema/Ndoni also poses security threat among community members as members of cult groups terrorize them. They rob and kill perceived enemies and their opponents in other cult groups.

\section{Implications of Findings to Community Education}

The issues reported in this study include mismanagement of fund and embezzlement, pipeline vandalization, abandonment of skills acquired, cultism, unnecessary demands by the youths among others. Most of these issues arise out of ignorance, lack of awareness, greed and poverty caused by unemployment. Community education as an indigenous education, when infused into the CSRs practices, will go a long way to address these issues. The leaders need to be conscientized on what it means to lead, they need to understand what self-help means and what it means to serve as leadership is about service. This awareness can be gained through leadership training through community education. Community education will equip them with knowledge, skills, understanding, courage, perceptivity and foresight in community leadership (Ewelum, (2014). Community leaders are the major drivers, agents and catalysts for community development, hence the need for leadership training programmes to strengthen their leadership skills for maximum development and sustainability.

The youths need to learn what it means to be self-reliant and economically independent. Their activities in oilproducing communities show that they are more comfortable with the little they are given by oil companies than using the skills provided for them to fend for themselves. They need to be taught to think beyond oil and think about life after oil. They need to understand as a popular saying that it is better to learn to fish than receiving fish donors who may run out of it or may not be willing to continue to give them the fish. With this consciousness, the youths will make use of the skills gained to establish themselves. Through community education, awareness should be created on the health implications of breaking of oil pipelines, vandalism and illegal refining of crude oil. They also need to understand that the loss of oil, man-hour and funds through vandalization of operation equipment affect the level of CSR of the companies to the communities. Community education is more suitable in addressing the issues raised in this study as it is education provided within the community with the resources found in the community.

\section{Conclusion and Recommendations}

This study has been able to establish that there have been corporate social responsibilities provided in the oilproducing communities in Rivers State though the level of benefits differs from one community to the other. From the foregoing, it can be concluded that apart from the conflicts between oil companies and communities, community members themselves have their issues that compromise CSRs' programmes and retard community development. Community education is also seen as a veritable tool that can address these issues to achieve peaceful co-existence among oil-producing communities for maximum benefits of CSRs of oil companies and sustainable community development. Based on the findings of this study and the conclusions drawn, the researcher recommends as follows:

1. Oil companies should as a matter of responsibility deal with leaders who have the interest of their communities at heart rather than their interest. 
2. Oil companies should also create community education centres in all their host communities where community members will be exposed to various training like leadership skill, literacy and people management skills among others.

3. Community members should also embrace all the training and educational programmes given to them to gain information, skills, knowledge and attitudes for positive change and maximum development.

4. Community member should elect or select where possible leaders who will represent community interest rather than their interest.

5. There is a need for an infusion of family life education in community education programmes for community members for families to give their children good moral upbringing to reduce crimes like cultism, robbery and pipeline vandalization among their youths.

\section{References}

Abiona, I.A. (2012). Community education practices in Nigeria. Lagos, Nigeria:Matrix Publishers.

Business Dictionary (2016a) Business Dictionary. Retrieved on 10th July, 2019 from

http://www.businessdictionary.com/definition/social- responsibility.htm

Crowther, D. \& Aras, G. (2008). Corporate social responsibility. Retrieved on 10th July, 2019 from www.bookboon.com

Ewelum, J.N. (2014). Community education needs of community-based organizations leaders in Anambra State, Nigeria. A PhD dissertation submitted to the Department of Adult Education and Extra-Mural Studies, University of Nigeria, Nsukka. Unpublished.

Igbara, F.N., Etu, N.O., Alaobari, C.M. \& Naenwi, M.O. (2014). Corporate social responsibility and the role of oil companies in community development in Rivers State Nigeria: An evaluation. Journal of Humanities \& Social Science 19(3) pp 92-97.

Kpolovie, P.J. \& Sado, A.A. (2016). CSR for conflict resolution in Niger Delta oil \& gas industry. British Journal of Environmental Sciences. 4(5) pp. 1-53.

Musa, A., Yusuf, Y., Mcardle, L. and Banjoko, G. (2013) carried out a research on titled "CSR in Nigeria's oil and gas industries: Perspectives of the industries. Retrieved on 15th July, 2019 from https://www.researchgate/publication

Nabiebu, M., Efombruh, O.E. \& Udo, E.J. (2019). CRS as a tool towards enhancement of corporate operation and environmental protection in the Nigerian Oil \& Gas sector. Journal of Civil \& Legal Services. 8(1).

Ojokheta, K.O. (2018). Achieving sustainable development through corporate social responsibility in an emerging economy. A lead paper presented at the 6th national conference of the Association for sustainable Development and Communities Integration of Nigeria (ASDCIN) in the University of Port Harcourt. Unpublished

The University of Edinburgh, Career Services (2017). Meaning of corporate social responsibility. Accessed on January $20^{\text {th }} 2020 \mathrm{from} \mathrm{https//www.ed.ac.uk/careers/your-future/options/occupation/csr}$

Total (2015). Corporate social responsibility report. Nigeria.

Ugwu, A. N. \& Mbalisi, O. F. (2019). Adult education, scope and programmes. In A. N. Ugwu \& O. F. Mbalisi (Eds) Contemporary issues in adult education. Port Harcourt, Nigeria: Pears Publishers International Ltd. 1-25. 
Ugwu, A. N. (2018). Assessment of women participation in self-help groups in Nsukka Local Government Area of Enugu State: Implications for community education. British Journal of Education. 6 (7) 83-94.

Ugwu, A.N. \& Mbalisi, O.F. (2016). Sociology of adult education. Port Harcourt: Chi Best Printing and Publishing Coy.

Uzoagu, I.F. (2015). Corporate social responsibilities of Shell Petroleum Development Company (SPDC) and Nigerian Ajip Oil Company (NAOC) for socio-economic development of the host communities in Rivers State.Journal of Economic \& Sustainable Development. 6(3) pp 251 -222. 